\title{
CLASSIFICATION OF LEPTOSPIRA
}

\author{
Analysis of Leptospiral Antigen
}

By

\section{MASAMI KITAOKA}

National Institute of Health, Tokyo

Recent advance in bacteriology indicates that microbes are, instead of being individually single antigen itself, consisted of various partial antigens in certain fixed structure each other, some situating on the surface and the others deep in the stroma, and play their respective roles in antigen-antibody reaction. Since Durham suggested so-called " mosaic theory" after having studied in detail of agglutination reaction during the year 1901, systematic analysis of antigen has been undertaken to make clear of the real phase in such partial antigens of various sorts through the results obtained in agglutination and absorption test. They are all aiming at the classification of the members of microbes reported by various authors in a disorderly manner into certain types and giving them a system in order to enable to prepare adequate and specific prophylactic serum and vaccines, simultaneously to trace and epidemiologically detect the source of infection. Among many meritorious works done along this line, classification of Salmonella family by Kaufmann-White ${ }^{1)}$ is one specially salient too. Leptospira is considered biologically somewhat akin to protozoa rather than bacteria. The fact that their antigenic structure is so complicated as to be compared with that in some of those enteric bacteria, as Kitaoka ${ }^{2,3)}$ had once stated while studying on Leptospira biflexa and as he ${ }^{1,5)}$ had again pointed out through results observed in researches on Leptospira icterohaemorrhagiae several years ago that this species of microorganism seems to display its immunological characteristic of combined effects of partial antigens of various sorts contained therein.

Many investigators in Europe (Uhlenhuth $\left.{ }^{6}\right)$, Schüffner ${ }^{7)}$, Schlossberger ${ }^{3}$ ), Kien-Hun ${ }^{9)}$, Parageorgiu ${ }^{10)}$ and Karakasevic ${ }^{11)}$ ), have also been of the same opinion, and it is quite reasonable that leptospira should, similarly to other bacteria, deservedly be subject to classification as well (Schüffner ${ }^{12}$ ) and Walch-Sorgdrager $\left.{ }^{13)}\right)$. 
As for the means to classify the leptospira into types, most of the investigators seem to have concluded from the results obtained in mutual group-reactions among leptospira strains or cross agglutination and other immunological reactions, excepting the works by Borg-Petersen ${ }^{14)}$, Schüffner $^{7)}$, Yamamoto ${ }^{15)}$ and Kitaoka ${ }^{16)}$ who have objectively described partial antigens proved through absorption test so far. This is not, however, due to the fact that most of the investigators in this line have not been interested in the antigenic analysis of leptospira, but due simply to the fact that the absorption test with leptospira is not easy when compared to that with ordinary bacteria. Kitaoka and his colleagues ${ }^{16)}$ have, however, carried out the works primarily according to Schüffner's ${ }^{17)}$ methods and succeeded in tabulating the results obtained objectively with various leptospira strains, and extended it even making factor sera specific for some partial antigens, details of which were reported at a scientific meeting of the Government Institute for Infectious Diseases in February, 1944.

Some of leptospira family reported hitherto are well set terminologically (Shiosawa ${ }^{18,19)}$, Arai ${ }^{20)}$, Inoue ${ }^{21)}$ and $\mathrm{Ono}^{22)}$ ), but others are left entirely out of order. Then the nomenclature in scientific designation and of various surnames on strains are confusingly put down without any correlationships each other, giving no avail when referred one to any known others.

As for leptospira species pathogenic to human, Schüffner has mentioned 19 strains in the year 193723) and 14 in the following year ${ }^{12)}$, while Shiosawa ${ }^{24)}$ referred to 13 strains in 1944 . The number of such strains of leptospira is expected to be further increased in future. In the above the review of literatures in the past on leptospira family actually pathogenic to human and animals is briefly summarized and the classification of leptospira family is described by means of absorption test in the present paper.

A. Strains isolated from human body:

1) Leptospira icterohaemorrhagiae.

Numerous strains of $\mathrm{L}$. icterohaemorrhagiae were isolated all over the world. Kaneko ${ }^{25}$ ) had made clear that they were all identical to the one first isolated by $\operatorname{Inada}^{26)}$ in 1914 from a case of Weil's disease in Japan. The agent is isolated not only from the case, but also from house-rats, carrier of leptospira (Miyajima ${ }^{27)}, \mathrm{Ido}^{28}$ ), Higuchi ${ }^{29}$ ), Kitaoka ${ }^{30}$ ) 
and many others), from dogs (Okell ${ }^{31)}$, Wirth ${ }^{32}$, Klarenbeek ${ }^{33)}$, Uhlenhuth $^{34,35,36)}$, Kubo ${ }^{37)}$, Kitaoka ${ }^{38,39)}$ and Yamamoto ${ }^{40)}$, and less frequently from cats, foxes; swine and so on (Klarenbeek ${ }^{11}$ ) as well as from sewerage in infected area (Cotter ${ }^{12)}$, Lumley ${ }^{43}$ ) and Kitaoka $\left.{ }^{44}, 45\right)$ ) and even from water in coal mine pits or on the pantry floor.

L. icterohaemorrhagiae is classified into two subspecies by agglutination test by Taylor ${ }^{46)}$ and through absorption test by Borg-Petersen ${ }^{14)}$, Schüffner ${ }^{17)}$ classified them into two types, the perfect and the imperfect, the former is known to be possessing one partial antigen which the latter is lacking and is represented by strain "Wijnberg" and the latter is represented by strain "Kantorowicz". Three leptospira strains, 2 human strains "Uchida" and "Asahara" and one rat-strain No. 23 which had been isolated by us and was sent to Schüffner on his request, were identified by him as his imperfect type. Therefore, it is undoubtedly sure that the imperfect type does exist in Japan. Such classification was also advocated in Japan by Yamamoto ${ }^{48}$ ) for leptospira strains isolated from dogs and by Kitaoka ${ }^{19}$ ) for strains from rats. However, it was unable to confirm that the rat strain $\mathrm{R} 132$, which had proved by us to contain one more antigen compared with the imperfect strain No. 1 , is corresponding to the perfect type "Wijnberg" strain because of lack of that particular strain in our laboratory (Table 1). At any rate, L. icterohaemorrhagiae is a microbe composed of various partial antigens and most of the strains reported in this country are of the imperfect type.

2) Leptospira hebdomadis.

It was first recovered from so-called seven-day fever (Nanukayami in Japanese) cases in Fukuoka Prefecture in 1916 and scientifically identified simultaneously by Ido50) and others. Sometimes, it is called Nanukayami leptospira. Nanukayami leptospira is a popular name for the causative agent of Nanukayami. On the other hand it is also called L. hebdomadis $B$ by mistake from the fact that Nanukayami is identical to the B type of Akiyami by Koshina ${ }^{51}$, on which it is described in detail in the following chapter. However, no more specific necessity of the word B is seen because $\mathrm{L}$. hebdomadis was reported as the causative agent of Nanukayami in 1917. Furthermore, it is to be pointed out that the term Akiyami B leptospira instead of $\mathrm{L}$. hebdomadis is sometimes used since it was made clear that both diseases, Akiyami B and Nanukayami, are caused by the same kind of leptospira. It must be kept in mind that the same 
disease as Nanukayami is widely distributed throughout Japan excluding the area northwards from Iwate and Akita Prefectures, and that various different names are given to the one same disease as an endemic disease. At any rate, it should be called the causative agent of so-called seven-day fever L. hebdomadis only to avoid the confusion in the past in the research of leptospira owing to such terms, Nanukayami leptospira, Akiyami B leptospira and L. hebdomadis B.

As regards antigenic structure of $\mathrm{L}$. hebdomadis, it is immunologically quite different from the other species of leptospira as shown in Table 2. It seems likely that there are some minor variant strains among the $\mathrm{L}$. hebdomadis group in agglutination test, however, it has not yet been able to detect such partial antigen in the variant strain through absorption test.

Distribution of this leptospira in Japan so far is so wide and common in rural areas with various names of disease as follows: in Fukuoka (Nanukayami by $\mathrm{Ido}^{50)}$ ), in Nagasaki (Hasami fever by $\mathrm{Abe}^{52}$ )), in Oita (Akke disease by Sato53)), in the southern Kyushu (by Aoki54)) and in Kochi (Odan-eki by Shimomura ${ }^{55)}$ ), in Okayama (Sakushu fever by Tagawa ${ }^{56)}$, Murakami ${ }^{57,58)}$, Kitaoka ${ }^{59}$ ) and Shiosawa $\left.{ }^{60)}\right)$, in Kyoto and Shiga (Nanukayami by $\left.\operatorname{Ido}^{50}\right)$ ), in Shizuoka (Akiyami by Koshina ${ }^{51)}$, Shiosawa ${ }^{60}$ ) and Kitaoka ${ }^{53,61,62)}$ ), in Chiba (by Shiosawa ${ }^{60)}$, Sahara fever by Kitaoka ${ }^{63)}$ ), in Ibaraki (by Kitaoka $\left.{ }^{64}\right)$ ), in Gumma (by Kitaoka ${ }^{55)}$ ), in Miyagi (by $\mathrm{Kitaoka}^{56)}$ ) and elsewhere contaminated with leptospira except of northern part of Japan.

Furthermore, the disease is commonly known all over the south-west Pacific areas, namely, in Indo-China (Vaucel ${ }^{67)}$ ), in Malaya (Fletcher ${ }^{68}$ ) and the East Indies (Schüffner ${ }^{12}$ ) and Mochtar ${ }^{39)}$ ). Spreading of this disease in European countries is also presumable from the report by Mino ${ }^{70}$ ) who found L. sejrö, which was discovered in Denmark and Italy, identical to this species. The leptospira is known in Japan to be transmitted by field rats (Mscrotus montebelli) as Ido ${ }^{50}$ ) has pointed out. This leptospira is recently reported by Mochtar ${ }^{59)}$ to have recovered not only from dogs but also from human in the East Indies.

3) Leptospira hebdomadis A.

The Autumn fever (Akiyami in Japanese) is a sort of leptospirosis as pointed out through isolation of leptospira by Kitamura ${ }^{71}$ in 1918, and the leptospirae were classified into two types, A and B, by Koshina ${ }^{51)}$ in 1923. The type $\mathrm{B}$ was identified with $\mathrm{L}$. hebdomadis while the type $\mathrm{A}$ being 
proved to be a new species. Koshina did not give any special name to the latter leptospira but described with the term L. hebdomadis type A in their publication. $\mathrm{Abe}^{52}$ has named this species as $\mathrm{L}$. autumnalis when isolated from Hasami fever cases as well as from field rats (Apodemus speciosus) trapped in an infected area. On the other hand, Hosoya ${ }^{72}$ ) published his work on this leptospira under the name of L. autumnalis A prior to Abe's report. Thus, denomination of this leptospira is still a pending problem. The late Dr. R. Inada was of the opinion that $\mathrm{L}$. hebdomadis $\mathrm{A}$ is adequate because this name had been described by Koshina in 1923 and both L. hebdomadis and L. hebdomadis A were found in the same infected area and caused almost similar clinical symptoms. In other words, it is impossible clinically to differentiate them each other but possible only by means of serological test. Consequently, the terms L. autumnalis, L. autumnalis A or Akiyami A leptospira are not preferable to be used for the purpose to avoid confusing scientific descriptions made with perfunctory common words.

L. hebdomadis A is always coexistent more or less in number with L. hebdomadis and the other leptospira in all endemic foci in L. hebdomadis mentioned above. Consequently, the disease under one same name in various endemic areas, for example, the Hasami fever in Nagasaki, must have been caused not only by L. hebdomadis but also by $\mathrm{L}$. hebdomadis A and others. This fact has been causing tremendous confusions to the discussions on the causative agent. In any case, it is also known to have spread as far as Indo-China, Malaya and their vicinity.

L. hebdomadis $\mathrm{A}$ is, although Taylor ${ }^{46}$ ) takes it identical to Andaman B leptospira, somewhat akin to the "Rachmat" strain isolated in the East Indies according to Walch-Sorgdrager ${ }^{13)}$. The Andaman B type is undoubtedly identical to L. grippotyphosa (Schüffner ${ }^{12)}$ ).

Schüffner ${ }^{23}{ }^{47)}$ pointid out, furthermore, that the relationships between L. hebdomadis A and the "Rachmat" strain may be similar to that between the perfect and imperfect types of L. icterohaemorrhagiae strains, therefore, he concluded that the "Rachmat" strain is one of L. hebdomadis A group.

It is suggested that L. hebdomadis A is composed of various partial antigens as is in the case of $\mathrm{L}$. icterohaemorrhagiae according to our result obtained in the agglutination test with 9 strains of L. hebdomadis A isolated from field rats. But no partial antigen has objectively been de- 
tected by absorption test among them. It is well known that this leptospira often demonstrates a strong cross reaction with $\mathrm{L}$. icterohaemorrhagiae $\left(\right.$ Hosoya $^{73)}$, Miyanaga ${ }^{74)}$ and Kaneko $\left.{ }^{75)}\right)$. It has been made clear by us that L. icterohaemorrhagiae has a common partial antigen with L. hebdomadis A, which had been detected by absorption test, but any common partial antigen to L. icterohaemorrhagiae has not been detected in $\mathrm{L}$. hebdomadis A (Tables 1 and 3 ). There is a cross reaction between $L$. hebdomadis $\mathrm{A}$ and $\mathrm{L}$. grippotyphosa in agglutination test. Kitaoka ${ }^{76}$ ) described once before that L. grippotyphosa is akin to L. hebdomadis A, though no common partial antigen among them has ever been detected by absorption test. The reservoir of $\mathrm{L}$. hebdomadis $\mathrm{A}$ is commonly field rats, Apodemus speciosus ( $\mathrm{Abe}^{77)}$, Kitaoka ${ }^{78-\mathrm{a}, \mathrm{b})}$ ) and, sometimes, other species of field rats, Microtus montebelli and Mus molossinus are (Shiosawa $^{79}$ and Inoue $^{80)}$ ).

It was occationally isolated from dogs (Fletcher $\left.{ }^{68}\right)$ ).

4) Leptospira australia A.

It was first reported by Kitamura ${ }^{81)}$ that the causative agent for so-called flume fever in a limitted area along the Tenryu River in Shizuoka Prefecture might be an additional species of leptospira distinguishable from any others known hitherto. But this strain was found by Kitaoka ${ }^{82}$ to be identical to L. hebdomadis A after inquisitive studies in detail. This area is long known to be an Akiyami endemic focus and both L. hebdomadis A and L. hebdomadis were isolated from the patients as well as from the field rats.

In 1938, so-called Akiyami C leptospira strain was isolated by Shiosawa $^{83)}$ and was denominated as $\mathrm{L}$. hebdomadis C. It was subsequently reported that $\mathrm{L}$. hebdomadis $\mathrm{C}$ is presumably prevalent not only along the Tenryu River but also in Okayama, where so-called Sakushu fever is known to be endemic (Shiosawa ${ }^{60}$ ) and Kitaoka ${ }^{59}$ ), in both Ibaraki and Miyagi (Kitaoka ${ }^{64}{ }^{66}$ ) by means of agglutination test and Pfeiffer's phenomenon. The intensity and frequency of its actual prevalence are naturally much less than those of Weil's disease, Akiyami and Nanukayami.

Yamamoto $^{48}$ ) has once named this species L. tenryuensis when he took it for a new species of pathogenic agent and has later ${ }^{15}$ ) reported that it was identified to L. australis A, "Ballico" strain (L. australis B in Schüffner's ${ }^{12)}$ table), which had been first isolated from cases during the rainy seasons when the natives plant and harvest sugar-canes in Australia. Therefore, tentative name, L. hebdomadis $\mathrm{C}$ proposed by 
Shiosawa ${ }^{83)}$, should be abandoned and the initial denomination L. australis A (Lumley) should be used.

As for the reservoir of this species of leptospira in Japan, Kitaoka and the other investigators have failed, after all, to find it. Cotter ${ }^{42}$ ) reported that this species of leptospira was isolated from house rats in Australia.

5) Leptospira bataviae.

A leptospira strain was isolated by Kitaoka ${ }^{84}$ from a case with symptoms resembling to Weil's disease in Gumma Prefecture, Japan, during the late summer, 1943, which was found undoubtedly different from any other sorts of strains found in the past in this country; the clinical findings of a patient were fever, muscular pain and hyperaemia of conjunctiva bulbi and recovered without developing any jaundice. First, it was considered to be a new type of Akiyami such as Akiyami D. This strain was, however, found identical to $\mathrm{L}$. bataviae later, and the fact ascertained was that the disease caused by $\mathrm{L}$. bataviae is existing also in this country although infrequently. The intensity and frequency of its prevalence and outbreaks are therefore of not much significance compared with the case of L. australis A as made clear by the results observed in surveys in Ibaraki and Miyagi Prefectures.

L. bataviae is first isolated from a human case with symptoms resembling to Weil's disease as well as from house rats by Walch ${ }^{85}$ ) in the East Indies in 1926, and later recovered from dogs (Mochtar ${ }^{86)}$ ), humans (Mochtar ${ }^{87)}$ ) and domestic cats (Esseveld $\left.{ }^{88},{ }^{89}\right)$ ). On the other hand, it was considered to be a new species of leptospira, designated L. oryzeti by Babuidieri $^{90}$ ) and L. mitis by Mino $^{70},{ }^{91}, 9^{2}$ ) for some time before such denominations were eventually abandoned when this leptospira was found identical to L. bataviae $\left(\mathrm{Mino}^{92}\right)$. The reservoir is, being not yet known in Japan, said to be house-rats by Dutch authors and to be field rats by $\mathrm{Mino}^{92}$ in Italy.

6) Leptospira canicola.

This is first isolated by Schüffner ${ }^{93}$ ) in Holland from dogs in 1932, and is known to have partial antigen in common with $\mathrm{L}$. icterohaemorrhagiae. Owing to a remarkable cross reaction with both $\mathrm{L}$. canicola and L. icterohaemorrhagiae in agglutination test, it is impossible to differentiate from each other but by absorption test ${ }^{7}$ ). The idea is supported by epidemiological and clinical observations that this leptospira is a new species distinct 
from the other leptospira group $\left.{ }^{94}\right)$. The species is found widely distributed among dogs not only in Europe (Klarenbeek ${ }^{33}$, Borg-Petersen ${ }^{14}$, Uhlenhuth $^{35},{ }^{36)}$, Wirth ${ }^{32)}$, and van der Walle ${ }^{95}$ ) $)$ but also in the United States $\left(\right.$ Meyer $^{96)}$ and Flander ${ }^{97}$ ) and in Japan (Kitaoka ${ }^{38},{ }^{29)}$ and Yamamoto ${ }^{40)}$ ). Several reports on human case infected with this leptospira have been published in Europe. Kitaoka ${ }^{59}$. presumed one human case in Japan immunologically. It is very interesting to note that this leptospira is usually isolated only from dogs and never from rats (Schüffner ${ }^{98)}$ and Kitaoka ${ }^{49}$.)

L. canicola has long been the subject of argument between Schüffner ${ }^{98}$ ) and Schlossberger ${ }^{99}$. Schlossberger ${ }^{100}$, 101) was of the opinion that L. canicola should belong to L. icterohaemorrhagiae group from both facts that the former holds a partial antigen in common with the latter and that the structure of partial antigens in each strain among the latter group is not always uniform. The facts mentioned above were supported by Lumley $^{43)}$, Kitaoka ${ }^{39}$ ) and Yamamoto ${ }^{40)}$. Schüffner stresses that L. canicola is a new species distinguishable from the known leptospira groups.

Uhlenhuth $^{36)}$, Kauffmann ${ }^{102)}$ and Bessemans ${ }^{108)}$ were of the opinion from serological stand point, and Klarenbeek ${ }^{33}$ ) from clinical observation that these two are different species. As referred to in the later chapter, Kitaoka is of the opinion that L. canicola belongs to L. icterohaemorrhagiae group but it is an independent species as shown in Tables 1 and 3.

7) Leptospira pyrogenes syn. febrilis.

Ohashi $^{104)}$ has isolated a leptospira strain from cases of so-called Weil's disease in Okinawa and also from rats caught in the same area in 1938. According to his first report, it was different from L. icterohaemorrhagiae, but in his second report, he claimed that they were identical. However, it was found later by him and Yamamoto ${ }^{48}$ ) that this strain is closely related to L. icterohaemorrhagiae with slight discrepancies in the partial antigens. Therefore, it was named L. okinawaensis by Yamamoto. A similar classification for this leptospira has been advocated by Kitaoka. After having observed on its partial antigens by absorption test as shown in Tables 1 and 3 , it was found to be a new species of leptospira though a cross reaction with other strains was noted, and was named tentatively L. okinawa according to usual custom of naming a newly discovered microbe strain to bear the name of place where it was reported as in the cases of Salmonella group strains.

The strain is later, however, by Yamamoto ${ }^{105}$ ), found to be identical 
to L. pyrogenes "Salinem" isolated by Baermann"106) in 1925, and to Sp. febrilis by Vervoort ${ }^{107}$ ) of the East Indies in 1922. The name of L. okinawaensis or L. okinawa were automatically cancelled accordingly.

Another leptospira strain "Zanoni" (L. australis B) isolated from coast fever, sugar-cane fever or bush fever cases in Australia is found to be closely related to L. pyrogenes although not fully identical (Schüffner ${ }^{108-a)}$, and Schüffner ${ }^{23}$ ) takes it as if the relationships between the perfect and imperfect types among L. icterohaemorrhagiae group which is considered to be existing also in Australia. This is, although differs from "Rachmat" strain (Schüffner ${ }^{108-b}$ ), a leptospira strain to be ranked in the L. ictrohaemorrhagiae group as already pointed out by Shiosawa ${ }^{18)}$ and Kitaoka.

L. pyrogenes is known to be spread by house-rats in Japan and Australia, by field-rats (Rattus brevicaudatus) and perhaps by swine (Mochtar) in the East Indies.

The seven species of pathogenic leptospira mentioned above are those known to be existing in Japan up to date, among which only L. icterohaemorrhagiae is existing only in the urban area (Kitaoka ${ }^{109,101)}$ ) and L. icterohaemorrhagiae (Toyama ${ }^{111)}$ ), L. hebdomadis A and L. hebdomadis in the rural districts (Aoki ${ }^{54)}$, Murakami ${ }^{59)}$, Shiosawa ${ }^{60}$ ) and Kitaoka ${ }^{59,64}$, 65,66)). The above facts are of practical significance for the intensity and frequency of their spreading. L. australis $A$, and $L$. bataviae are not often found in the rural areas as mentioned above and $L$. pyrogenes is immunologically considered to be existing in southern Kyushu (Kitaoka ${ }^{112)}$ ).

The prophylaxis against the leptospirosis has been undertaken with great success for the workers in the restaurants in the urban areas with L. icterohaemorrhagiae vaccine and for the farmers actually working in the endemic areas with the combined vaccine of $L$. icterohaemorrhagiae, $L$. hebdomadis, L. hebdomadis A, L. australis A and L. bataviae (Kitaoka ${ }^{64}$ )).

8) Leptospira grippotyphosa.

This leptospira was isolated by Tarassoff $\left.{ }^{113}, 114,115\right)$ ) in Russia in 1928, and was found apparently to be different from L. icterohaemorrhagiae, L. hebdomadis A or L. hebdomadis.

Prior to this discovery, Rimpau ${ }^{16}$ ) had clinically reported that the disease might be due to a leptospira, and Brill117) found, morphologically, a leptospira-like microbe in smear preparations from the cases, the liver and kidneys of field rats. Dinger ${ }^{118)}$ was of the opinion that this agent is 
not identical to L. icterohaemorrhagiae.

Clinical symptoms of the patient were 'somewhat similar to those of Nanukayami and Akiyami (Hoffman ${ }^{119}$ ) and Schulz ${ }^{120)}$ ). Kitaoka ${ }^{76}$ ) pointed out that it is a new species though its cross reaction is observed to some extend with anti-L. hebdomadis A serum. Close relationship between $\mathrm{L}$. hebdomadis A and L. grippotyphosa was also pointed out by Schlossberger $^{99)}$ and Yamamoto ${ }^{121)}$.

There is still no evidence that this leptospira is existing in Japan. It is, however, widely spread in Russia and Germany (Rimpau ${ }^{122}$ ) , in France (Osterwald ${ }^{123)}$ ) and, likely, in other places in Europe. Prevalence in Andaman Islands is also presumable from the fact that the species was identified with Andaman B leptospira of Taylor ${ }^{16)}$ as Schüffner ${ }^{12}$ ) has mentioned. It was pointed out by Walch-Sorgdrager ${ }^{13)}$ that it is akin to "Rachmat" strain. Yamamoto"18) takes it for a sub-species of L. hebdo. madis $\mathrm{A}$ from the result obtained in cross reaction. The reservoir are, in Europe, certain field-rats (Schüffner).

9) Leptospira sejrö.

This is another leptospira strain distinguishable from any other species hitherto known, isolated from the blood and urine of a patient at Sejrö Island, Denmark in 1938 by Borg-Petersen ${ }^{14}$ ) who made clear later that it showed a cross reaction with $\mathrm{L}$. hebdomadis and the " $\mathrm{HC}$ " strain from the $\operatorname{dog}$ in the East Indies. It was also reported by $\mathrm{Mino}^{92}$ ) that it is prevalent in northern Italy. Fairly wide distribution, furthermore, over European countries is presumable. Borg-Petersen ${ }^{14)}$ recovered this leptospira also from kidneys of mice (Mus spicilegus).

10) "Rachmat" strain and "Baerman" strain.

In 1923 Baerman 124,125) isolated a leptospira strain "Baerman" from a case of so-called "mild leptospirosis" commonly prevailing in the East Indies which is said to be different (Johnson ${ }^{126)}$ ) from "Rachmat" strain isolated by Wolff ${ }^{12 i)}$ in 1925 . The latter is understood to be a subspecies of L. hebdomadis A (Schüffner ${ }^{23)}$ ), though it is still left opened to later discussions.

"Rachmat" strain was recently isolated from the natives in the East Indies excepting Sumatra by Mochtar ${ }^{128}$ ) who presumed that it is prevalent also among swine ${ }^{129}$. Brown ${ }^{130}$ ) reported that it is spread among the natives in Andaman Islands too. Schüffner concluded that the strain "Rachmat" and L. febrilis "Salinem" are two different ones. 
11) Leptospira andaman A.

Taylor ${ }^{46)}$ and Goyle have reported of L. andaman A existing in addition to strains Andaman B and "Rachmat" (Brown ${ }^{130)}$ ), and L. andaman $A$ is said to be independent from any other known species.

12) Leptospira australis B.

This was isolated from cases of Australian coast-fever or bush-fever as well as from rats concerned by Lumley ${ }^{13)}$ in 1937. It is distinguishable from L. australis A and from "Pomona" strain but rather akin to L. icterohaemorrhagiae and L. canicola in agglutination test. This strain differs from either L. hebdomadis A, "Baerman" strain or L. andaman B.

13) "Pomona" strain.

Johnson ${ }^{126)}$ has pointed out in 1936 that "Pomona" strain is a new species of leptospira which is distinctly different from any of those isolated from Australian coast-fever cases especially "Ballico" and "Zanoni" strains. This was accepted by Lumley ${ }^{13)}$ too. Clayton ${ }^{131)}$ found that this is somewhat akin to "Rachmat" and "Baerman" strains. The strain is reported to have been isolated from dogs and from pigs (Mochtar ${ }^{129)}$ ) in the East Indies.

The following 4 strains were isolated in Sumatra.

14) Leptospira haemoglobinuria.

15) “Djasiman" strain.

16) "Benjamin" strain in Deli, Sumatra.

17) "Sarmin" strain in Atjeh, Sumatra.

The following 2 strains were found by Vaucel in Indo-China.

18) Leptospira kebler.

19) Leptospira tuyen-quang.

L. tuyen-quang is claimed by Vaucel67) to be different from L. icterohaemorrhagiae in its antigenic structure though a strong cross reaction was seen between them.

Two other strains of leptospira were isolated by Fletcher ${ }^{68)}$ in Malaya.

20) "Eruthyan" strain.

21) "Nallathamby" strain.

22) Das Gupta132) announced recently that there exists a strain not identified to any known strain in Calcutta.

It must be pointed out that there are numerous strains among strains mentioned above under 10)-22) reported without any specific classification, and confusing one another in their descriptions, and thus, further com- 
plications are expected by addition of newly isolated strains in future. Therefore, further studies on immunological relationship between all of the strains necessary for identification and classification of leptospira are urgently needed.

B. Leptospira strains found exclusively among animals.

1) Leptospira bessemans.

Bessemans ${ }^{133)}$ has recovered this strain from mice in Europe in 1928.

2) Leptospira javanica.

It was first recovered by Sardjito ${ }^{134)}$ and it was made clear by Esseveld ${ }^{135)}$ that it is different from any other leptospira strain ever known, although immunological relation to $\mathrm{L}$. hebdomadis $\mathrm{A}$ has not yet been completely made clear. According to our result, it is quite different from L. hebdomadis A. Esseveld ${ }^{87,88)}$ recovered it from Rattus brevicaudatus as well as from domestic cats in the East Indies.

3) Leptospira " $\mathrm{HC}$ " strain.

It was isolated from dogs.

4) Leptospira “R. 173" strain.

It was recovered from Rattus brevicaudatus by Sardjito ${ }^{37)}$ in 1939.

5) Leptospira "90 C" strain.

It was isolated from kidney of a certain species of bat (Cynopterus family). Another immunologically independent leptospira strain was isolated from the bat of the same species by Collier ${ }^{138)}$ in 1939. That is

6) Leptospira " $3522 \mathrm{C}$ ".

Four strains 3), 4), 5) and 6) were all found in the East Indies.

C. Geographycal distribution of various kinds of leptospira.

It is very important in the preventive medicine to describe the geopraphical distribution of various kinds of leptospira all over the world. From the reports mentioned above, it is briefly summarized as follows. Seven species, L. icterohaemorrhagiae, L. hebdomadis A, L. hebdomadis, L. canicola, L. bataviae, L. pyrogenes and L. australis A in Japan; 5 strains, L. icterohaemorrhagiae, L. hebdomadis A, L. hebdomadis, L. kebler and $\mathrm{L}$. tuyen-quang in Indo-China as reported by Vaucel ${ }^{139)} ; 3$ strains, L. andaman A, L. andaman B (L. grippotyphosa) and "Baerman" strain in relation with "Rachmat" strain in Malaya as reported by Taylor ${ }^{46)}$ and Brown ${ }^{130)}$; 10 strains isolated from human cases in the East 
Indies, namely, L. icterohaemorrhagiae, L. hebdomadis A, L. hebdomadis, L. bataviae, L. pyrogenes, "Baerman" strain in relation with "Rachmat" strain, L. haemoglobinuriae, "Djasiman", "Benjamin" and "Sarmin" strains and 6 from animals, namely L. javanica, "Pomona", " $\mathrm{HC}$ ”, “ $\mathrm{R}$ 173 ", " $90 \mathrm{C}$ " and " $3522 \mathrm{C}$ " strains; 2, L. icterohaemorrhagiae and an unclassified strain in India; 4, in Australia, L. icterohaemorrhagiae, L. australis A ("Ballico" strain), L. australis B ("Zanoni" strain) closely related to L. pyrogenes and "Pomona" strain; 5 from human cases, L. icterohaemorrhagiae, L. grippotyphosa, L. sejrö, L. bataviae (oryzeti, mitis) and a strain from animals (Bessemans) in Europe; and 2 strains, L. icterohaemorrhagiae and L. canicola in America to date. Furthermore, strains are expected to be discovered from all over the world especially from the East Indies where leptospira is widely spread not only among the human beings but also among various kinds of animals (Esseveld ${ }^{140}$ )).

D. Classification of leptospira.

Many strains of leptospira have been thus reported from every corner of the world ever since it was first discovered by Inada that L. icterohaemorrhagiae is the causative agent for Weil's disease. On the other hand, it was made clear that there are many mild leptospirosis in various parts of the world, the causative agent of which are immunologically different from that of Weil's disease. Some of these strains have been adequately classified, but most of them have been left in coarse situation as to their classification, identification and descriptions in detail. Therefore, it is desirable to arrange them as is seen in the case of various sorts of pathogenic agents and parasites.

Classification of various leptospira strains was undertaken from clinical standpoint, namely through the clinical symptoms, however, it was not reasonable since there are many cases of abortive from or inapparent infections even in Weil's disease, which is a severe disease with high mortality rate as reported by Ido $^{141)}$, Kitaoka $\left.{ }^{109}, 110\right)$, Baerman ${ }^{124)}$, Hamilton ${ }^{142)}$ and Blumenberg ${ }^{143)}$. Shiosawa ${ }^{144}$ attempted to classify various kinds of leptospirosis roughly into two types, icteric and non-icteric, ranking Weil's disease, Akiyami, Pyrogenes-, Batavia-, Rachmat- and Baerman-types diseases in the former, and Nanukayami, harvest fever including Sejrö-type disease, Canicolatype disease and the coast-fever including Ballico- and Pomona-types diseases in the latter, from the fact that the former is much inclined to icteric sym- 
ptom while the other not. This classification may not always be of much significance. This idea was based on the first report of Inada ${ }^{145)}$ who had classified them clinically into two groups, Weil's disease group, the severer form group, and Akiyami group, the milder one. Shiosawa ${ }^{146,}$, 147, 148, 149) agreed first with Inada on that and then he ${ }^{\text {?4) }}$ used the term "milder leptospirosis" instead of Akiyami. Recently, he ${ }^{144)}$ described icteric and non-icteric forms. Such a clinical classification is neither correct in epidemiological point nor of value for preparing prophylactic vaccines and antisera, althought it might be of singificance in judging the prognosis of the case.

Classification of leptospirosis in neither expectant to make through seasonal occurrence or occupational dispositions, nor is proper to sort them. on account of reservoir or the causative agents, for examples, L. hebdomadis A from a field rat, Apodemus speciosus, L. hebdomadis from another field-rat, Microtus montebelli, L. canicola from dogs and so on, since such reservoirs of various kinds of leptospira are found much varying with time and circumstances.

Virulence of various leptospira strains for guinea-pigs would by no means as well be of any avail in classification of the disease, for virulence of any strain would be attenuated during the course of cultivating on artificial culture medium and is not always the same among the freshly isolated strains of a same species. It was pointed out by us ${ }^{77)}$ that it had been impossible to differentiate L. hebdomadis A from L. hebdomadis merely on the basis of their virulence. The same idea was mentioned by Sato ${ }^{53}$. Niinome's report ${ }^{150)}$ that virulence of a L. hebdomadis strain which had been enhanced through mouse-passages was similar to that of $\mathrm{L}$. icterohaemorrhagiae is doubtfull. Anjo ${ }^{151}$ ) has found that the oligodynamic action of heavy metals as well as of hydrogen ion concentration upon various pathogenic leptospira strains was different in each leptospira species. But the classification through oligodynamic action was neither reasonable nor practicable.

Biological characters specifically applicable in identification of various microorganisms, especially fermentative action upon carbohydrates, has not yet been known in various leptospira strains for the purpose of their classification. The morphological studies on various strains is of no avail to their classification to date. Kimura ${ }^{152}$ ) has recently made an attempt to classify various microorganisms through the studies on internal structure- 
observed under electron-microscope. According to our experience, the classification of leptospira may be possible from morphological investigation by using electron-microscope.

Classification of leptospira could also be attempted by chemical analysis as well as from antigenic structure of surface and deep part in each leptospira. Carlinfanti ${ }^{153}$ ) has practiced the complement fixation test using the lipoid extract of stromatic substance in alcohol from various leptospira strains and found that there was a common antigen extracted in alcohol among the leptospira family. Almost the same results were obtained by us in a limitted experiment.

It is believed that the most trustworthy method for classification of various leptospira strains is to be based on the results observed in the specific antigen-antibody reactions, especially in the absorption test in the agglutination reaction as in the case with Salmonella family. However, this method would not be reliable if there occurred any spontaneous mutation or variation in the antigenic structure of leptospira as seen in the cases with other microorganisms mentioned by Okamoto ${ }^{154)}$. Uhlenhuth ${ }^{155)}$, Zuelzer ${ }^{156)}$, Sardjito ${ }^{157)}$ and others said that leptospira has a property to form a variant. In that case, the classification of leptospira on the basis of antigen-antibody reactions is not reliable for those investigators.

Contrary to those reports $\left.\mathrm{w}^{158}\right)$ have never experienced such a variation in the antigenic structure of leptospira. Besides, many workers such as Dinger ${ }^{118)}$, Borg-Petersen ${ }^{14}$, Blumenberg ${ }^{143)}$, Lumley ${ }^{43)}$, Shiosawa ${ }^{3}$, Tsuge 159), Sugimoto ${ }^{160)}$ and Yamamoto $^{48)}$ are of the same opinion as we are.

We have been collecting various leptospira strains recovered not only in Japan but also in all over the world since 1937. Owing to the outbreak of Sino-Japanese conflict, all contacts with the East Indies, from where most important reports on the subject were being obtained, were disrupted. However, the following strains were forwarded from Europe : namely, L. canicola, "Utrecht IV" strain, from Schüffner of Holland; L. grippotyphosa, "Straubing" and "Moscow V" strains, from Schlossberger of Robert Koch Institute, Germany; L. bataviae (L. mitis), "zan." and "acc." strains, from Mino of Milano University, Italy. But another lot of strains, L. javanica, "Pomona" - "Mezzano", L. australis A "Ballico", L. australis B “Zanoni”, L. sejrö, L. pyrogenes “Salinem”, "Swart van Tienen”, ", Rachmat" and others, which had been forwarded by Mino, have reached us. But unfortunately, they were all dead because it took more than 
one year for transportation to reach our laboratory.

Three strains, L. pyrogenes, L. javanica and L. bataviae from East Indies were given by Yamamoto who had obtained them from East Indies during the Pacific War, through the Japanese Army. All of the 11 strains of leptospira, L. icterohaemorrhagiae "No. 1" and "R. 132 ", L. canicola “Utrecht IV", L. pyrogenes "Okinawa”, L. hebdomadis A, L. grippotyphosa "Moscow V", L. australis A, L. hebdomadis, L. mitis, L. bataviae and $L$. javanica, which we could collect were subjected to the investigation for the antigenic analysis. Monovalent immune rabbit serum against each of 11 strains mentioned above was prepared for the purpose of their immunological properties. Cross agglutination test with each other revealed. that L. javanica and L. hebdomadis are apparently independent species. each other, 3 strains of L. icterohaemorrhagiae, L. canicola and L. pyrogenes are to be grouped in one, and L. hebdomadis A, L. grippotyphosa and L. australis A in one group. However, it is also suggested that the latter 3 strains, L. hebdomadis A, L. grippotyphosa and L. australis A, are grouped in two groups, the first 2 strains and the remaining one. It is also presumable that 5 strains, L. icterohaemorrhagiae, L. canicola, L. pyrogenes, L. hebdomadis $\mathrm{A}$ and L. grippotyphosa, have same relation each other and that both strains L. mitis and L. bataviae are in a same group as shown in Table 4.

The assumption of classification of leptospira based on cross agglutination test should be criticized by means of absorption test. L. bataviae and L. mitis are found likely to be nothing but one species bearing two different names in antigenic structure which are totally different from 9 other strains mentioned above, and each of L. javanica and L. hebdomadis is entirely different each other as well as from the remaining 10 strains in the antigenic structure though the anti-L. javanica serum agglutinates L. icterohaemorrhagiae to some extend. Those three strains, L. hebdomadis A, L. grippotyphosa and L. australis A, are appearing in cross agglutination test as if they contain a common partial antigen; however, such a common partial antigen could not be decisively proved in the absorption test. Therefore, it may be concluded, after all, that those three are of different. species.

On the contrary, L. icterohaemorrhagiae (2 strains), L. canicola and L. pyrogenes were first presumed to have some common partial antigens among them in cross agglutination test, and then a common partial anti- 
gen was detected by means of absorption test. Detailed study on the antigenic structure of leptospira was performed by Sakamaki, Kitaoka's assistant. Thus we successfully prepared a factor serum common among 3 species, L. icterohaemorrhagiae, L. canicola and L. pyrogenes. These findings are almost the same as those obtained by Yamamoto.

It has also been made clear by us that there are two types among strains of L. icterohaemorrhagiae, one of them being identified with Schüffner's incomplete form and being common in Japan and the other being holding additional partial antigen detected by absorption test, and that $\mathrm{L}$. icterohaemorrhagiae contains a partial antigen in common with L. hebdomadis though the former has other partial antigens which are not in common with the latter as mentioned above, being not related to any of the other 7 strains. Thus we propose to designate a group of those 3 species as the group " A" to separate from others. Table 5 illustrates classification of leptospira among 11 strains, which we were able to collect up to date, by means of absorption test. Refering to the table, it must not be ignored that there are common partial antigens which are not detectable by means of absorption test among the leptospira, but are presumed their existence by cross reactions. We would propose to give the principal partial antigen in each strain large Roman numerals (I, II, III, IV, V, VI, VII, VIII, XI), detectable partial antigen with small Roman numerals (i, ii, iii, iv) and non-detectable but presumed one by cross agglutination tests with Arabic numerals. Each symbol is not of the same value as is in the case of Salmonella group. Some partial antigens are more potential than others within leptospira, so that we would arrange these symbols in order by subnumber on their right side as shown in Table 5.

We do not, of course, believe that various leptospira strains could be consisted of such a few number of partial antigen and there would remain many problems to be solved before our table is completed.

The ideas that both L. icterohaemorrhagiae and L. hebdomadis are in the same species (Matsuzaki ${ }^{161)}$ ) and that various leptospira strains are monistic (Uhlenhuth ${ }^{155)}$ and Zuelzer ${ }^{156,162)}$ ) are contradicting with the fact revealed above. If the immunological reaction especially 'the antigenic structure of leptospira were not fixed, it would lead us to no conclusion.

Now the time has become ripe to classify various leptospira strains. Some of them are still lacking orderly description and not yet denominated. They should be investigated immunologically first and then classified. 
Along this line we endevoured to collect any strain recovered throughout the world, however, the number of strains we had been able to collect were limitted owing to the outbreak of the War. I hope to have opportunity to collect much more strains for their classification and supplement to our Table 5 .

\section{SUMMARY}

I. There are numerous reports concerning various leptospira strains. Some of those strains have been denominated orderly following their immunological relationship between each other, however, the others are not yet under detailed study. Now the time has become ripe to classify various leptospira strains as is in the case of Salmonella group.

There is no evidence that correlated variations or impressed variations occur among them as general phenomena in the course of cultivation on ordinary media as is in the case of Salmonella group.

The hypothesis of antigen mosaic within the single leptospira cell has been published in a more detailed study of leptospira agglutinations.

The antigenic analysis by selective quantitative absorption of agglutinins was undertaken according to Schüffner's method.

Collection of the various kinds of leptospira from all over the world was attempted but was unsuccessful owing to the outbreak of the War. Eleven strains of leptospira have been collected for antigenic analysis with monovalent immune rabbit sera against each strain, namely two strains of L. icterohaemorrhagiae "No. 1" and " R 132 ", L. canicola "Utrecht IV", L. hebdomadis A, L. hebdomadis, L. australis A, L. grippotyphosa "Moscow V", L. pyrogenes "Okinawa", L. bataviae, L. mitis (oryzeti) and L. javanica.

From the results of the cross agglutination tests with 11 strains, it is clear that L. hebdomadis, L. bataviae and L. javanica occupy each special place of their own independently. Among some of 11 strains, cross reactions occur, apart from a few very low ones showing titer of 10 . In the cases of agglutinations between one group (L. icterohaemorrhagiae, L. canicola and L. pyrogenes) and the other (L. hebdomadis A, L. grippotyphosa and $L$. australis $A$ ), such reaction may occur up to the titer as high as 100,300 or 1000 . This fact may be suggesting that the leptospira in each group mentioned above have part of their antigenic structure in common. This assumption is to be solved by antigenic analysis through 
cross agglutinin absorption tests.

From the results of cross agglutinin absorption tests, it can be said that the identity of both L. bataviae and L. mitis is reconfirmed and the three strains, L. bataviae, L. hebdomadis and L. javanica, have quite different antigenic structures each other.

There is no detectable common partial antigen among three strains, L. hebdomadis A, L. grippotyphosa and L. australis A, though the existence of such antigen was presumed by cross agglutination tests. Each of them belongs to a different type. The fact that all strains of $\mathrm{L}$. icterohaemorrhagiae have not necessarily the same antigenic constitution has been assumed by many investigators including ourselves. Now we can actually divide them into two groups by means of antigenic analysis, one with a partial antigen detectable through absorption test while the other is lacking such an antigen. One of them corresponds to Schüffner's incomplete biotypus, however, it is not clear whether or not the other one corresponds to his complete biotypus because Schüffner's complete biotypus strain was not available. Occasionally, cross reaction occurs between L. icterohaemorrhagiae and L. hebdomadis A. From the standpoint of antigenic constitution, it was clarified that $\mathrm{L}$. icterohaemorrhagiae has a partial antigen in common with $\mathrm{L}$. hebdomadis A. The antigenic constitution of so-called A group strains (L. icterohaemorrhagiae, L. canicola and L. pyrogenes) is complicated. Each strain has its own principal partial antigen and accessory ones which are in common with some of the other strains. I was successful in obtaining the factor serum (III) common among A group strains. Those three strains are different types each other, even though they have more or less partial antigens in common.

It must not be ignored that there are common partial antigens which are not detectable by means of Schüffner's absorption tests but assumed by paraspecific reactions among the leptospirae. I would propose to give the principal partial antigen in each strain large Roman numerals (I, II, III, IV, V, VI, VII, VIII, IX), detectable partial antigen with small Roman numerals (i, ii, iii, iv) and non-detectable but assumed antigens by cross agglutination tests with Arabic numerals. Each symbol is not of the same value as is in the case of Salmonella group. Some partial antigens are more potential than others within leptospira, so that I would arrange these symbols in order by subnumber on their right side. For example schematical formula of $\mathrm{L}$. icterohaemorrhagiae " $\mathrm{R} 132$ " is described as $I \mathrm{ii}_{2} \mathrm{iii}_{3} \mathrm{iv}_{3} 5_{1} 6_{2} 9_{2}+\mathrm{a}$. 
II. Since 1944 many reports have been published on leptospira (Rosenbaum $^{164)}$, Meyer ${ }^{165)}$, Stavitsky ${ }^{166)}$ and Alston $\left.{ }^{167)}\right)$, especially on the new types of leptospira, L. poi, L. saxkoebing, L. suis, L. ballum (Borg-Petersen ${ }^{163)}$ ) and L. bovis $\left(\right.$ Btesh $^{169)}$ ) as well as on the serological typing of leptospira (Wolff $\left.{ }^{170}\right)$.

The achievements in isolation of leptospirae from domestic animals, especially from cattle (Bernkopf ${ }^{171)}$, Ungar ${ }^{172)}$ and Baker ${ }^{173)}$ ) and pigs (Guida ${ }^{174,175)}$ ) in various countries are considered highly significant for the epidemiology of leptospirosis.

The necessity for an international centre for typing of leptospira strains, as is in the cases of Salmonella and Influenza, is strongly emphasized.

(The present research works have been carried out with the Grant from the Ministry of Education. The contents of the present pape excepting Summary II have been read at the Scientific Meeting of the Government Institute for Infectious Diseases on February 14, 1944.)

\section{REFERENCES}

1) Salmonella Subcommittee: The Third International Congress for Micro biology, New York, Repot of Proceedings 1939.

2) Shiosawa, S., Anjo, S. \& Kitaoka, M.: Studies on Leptospira biflexa (II) ; Iji-Shimbun, No. 1236, 678-690, 1928 (in Japanese).

3) Shiosawa, S., Kitaoka, M. \& Inoue, K.: Studies on Leptospira biflexa (III) ; Nihon-Densenbyo-Gakkai Zasshi, 7, 1177-1197, 1933 (in Japanese).

4) Kitaoka, M.: Ueber die Typenfrage der Rattenstaemme von Leptospira icterohaemorrhagiae; Nihon-Densenbyo-Gakkai Zasshi, 6, 1249-1274, 1933 (in Japanese).

5) Kitaoka, M.: Zur Typenfrage der Leptospira icterohaemorrhagiae und pseudo-icterohaemorrhagiae; Zbl. Bakt., I. Orig., 143, 465-468, s1939.

6) Uhlenhuth, P.: Zur Typenfrage der Spirochaeta isterogenes und pseudoicterogenes; Festschrift furr Prof. B. Nocht, 636-643, 1937.

7) Schüffner, W.: Recent work on leptospirosis; Tr. Roy. Trop. Soc. Med., 28, 7-37, 1934.

8) Schlossberger, H., Grills, J. \& Scheele, L.: Ueber das Vorkommen von Typen bei der Spirochaete der Weilschen Krankheit; Klin. Wschr.," 14, 1113-1137, 1935.

9) Bau, Kien-Hun: Untersuchungen über die Weilspirochaete; Zbl. Bakt., I, Orig., 138, 413-424, 1937.

10) Papageorgiu, S.: Ueber die Komplementbindungsreaktion bei Leptospirosen; Z. Imm. Forschg., 94, 489-505, 1938.

11) Karakasevic, Bogdan: Serologische Untersuchungen über die Spirochaete des Feldfiebers ("Spirochaeta grippo-typhosa"); Z. Imm. Forschg., 96, 427-440, 1939. 
12) Schuffner, W.: Zur Systematisierung der Leptospiren; Acta Con. Tert. Trop. Morb., Amst., 407-415, 1938.

13) Walch-Sorgdrager, B.: Leptospiroses; Bull. of the Health Organization, League of Nations, 8, 143-386, 1939.

14) Borg-Petersen, C.: Leptospirenuntersuchungen in Daenemark; Acta Con. Tert. Trop. Morb., Amst., 396-406, 1938.

15) Yamamoto, S.: Classification of leptospira by means of agglutination and absorption tests; The Scientific Meeting of the Government Institute for Infectious Diseases on May, 1944 (reported in Japanese).

16) Kitaoka, M. \& Sakamaki, Y.: Studies on antigenic analysis of various kinds of leptospira (I); Jikken-Igaku Zasshi, 28, 284-286, 1944 (in Japanese).

17) Schuiffner, W. \& Bohlander, H.: Zur Technik des Absaettigungsversuchs mit Leptospiren; Zbl. Bakt., I, Orig., 144, 434-439, 1939.

18) Shiosawa, S.: Immunological differentiation of various kinds of leptospira; Iji-Shinbun, No. 1221, 1219-1248, 1927 (in Japanese).

19) Shiosawa, S.: On leptospira and leptospira disease; Nihon-DensembyoGakkai Zasshi, 9, 213-234, 1934 (in Japanese).

20) Arai, T.: Relation of L. icterohaemorrhagiae to the other leptospira by means of Rieckenberg's phenomenon; Tokyo-Iji-Shinshi, 52, 201-209. 1928 (in Japanese).

21) Inoue, S.: On Rieckenberg's phenomenon. II. Comparative studies of this phenomenon with other immunological tests in various kinds of leptospira; Juzenkai Zasshi, 33, 719-747, 1928 (in Japanese).

22) Ono, S.: Recent studies on leptospirosis; Nisshin-Igaku, 28, 1161-1184, 1939 (in Japanese).

23) Schüffner, W., Gispen en Bohlander, H.: Voortgezette pogingen tot ordening der leptospirae; G. T. v. N. I., 79, 2470-2478, 1939.

24) Shiosawa, S. \& Kubo, I.: On leptospirosis in Far East; Shindan to Chiryo, 30, 727-740, 1943 (in Japanese).

25) Kaneko, R. \& Morihana, S.: Untersuchungen über die Identität der Spirochaeta icterohaemorrhagiae (Inada und Ido) und der Spirochaeta icterogenes (Uhlenhuth und Tromme) und über des Verhalten der Spirochaeta hebdomadis, des Erregers des Siebentagefiebers ("Nanulayami"), gegenūber der Spirochaeta icterogenes; Z. Imm. Forschg., 31, 201-221, 1921.

26) Inada, R. \& Kraneko, R.: Leptospirosis ieterohaemorrhagica in Japan. Pathological findings in the infected test animals; Nihon-Byori-gakkai Kaishi, 5, 107-115, 1915 (in Japanese).

27) Miyajima, M.: History of Weil's disease; Saikingaku Zasshi, No. 247, 664-665, 1916 (in Japanese).

28) Ido, T., Hoki, R. \& Ito, K.: Rat as reservoir of etiologic agent of Weil's disease and mode of infection connected with it. Further, studies on preventive measure against the disease; Tokyo-Iji-Shinshi, 1387, 1439, 1916 (in Japanese).

29) Higuchi, S.: Positive rate of leptospira found in rats in various parts of Japan; Tokyo-Iji-Shinshi, 2722, 2797, 1930 (in Japanese).

30) Kitaoka, M., Inoue, K. \& Wakana, S.: Positive rate of leptospira. among house rats by means of Rieckenberg's phenomenon (I); NihonDensenbyo-Gakkai Zasshi, 6, 1027-1041, 1932 (in Japanese). 
31) Okell, C. C., Pugh, L. P. \& Dalling, T.: Leptospiral jaundice in dogs; Brit, Med. J., 1, 266, 1925.

32) Wirth, D.: Die Leptospirose (Weilsche Krankheit) bei Tieren; Wien. Klin. Wschr., 50, 1115-1117, 1937.

33) Klarenbeek, A.: Klinische Statistik der Leptospirosen des Hundes; Zbl. Bakt. Orig., 142, 83-86, 1938.

34) Uhlenhuth, P. \& Zimmermann, E.: Zur Epidemiologie und Therapie der Weilschen Krankheit; Zbl. Bakt. Ref., 119, 490, 1935.

35) Uhlenhuth, P. \& Zimmermann, E.: Hunde als Traeger der Spirochaeten von Weiltypus; Dtsch. Med. Wsehr., 62, 891-893, 1936.

36) Uhlenhuth, P.: Epidemiologie der Weilschen Krankheit; Acta Con. Tert. Trop. Morb., Amst., 357-371, 1938.

37) Kubo, I.: Leptospira from dogs from epidemiological point; Tokyo-IjiShinshi, 52, 560-583, 1938 (in Japanese).

38) Kitaoka, M.: L. canicola in Japan; Jikken-Igaku Zasshi, 24, 861, 1940 (in Japanese).

39) Kitaoka, M.: Further studies on L. canicola in dogs; The 15ih Rengo Biseibutsu Gakkai Kiroku, 36-41, 1941 (in Japanese).

40) Yamamoto, S.: Studies on leptospirosis in dogs (1); Nihon Juigaku Zasshi, 2, 39-70, 1940 (in Japanese).

41) Klarenbeek, A.: Einige neuere Untersuchungen 'über Leptospirosen bəi Tieren; Acta Con. Tert. Trop. Morb., Amst., 381-386, 1938.

42) Cotter, T. J. P. \& Sawers, W. C.: A laboratory and epidemiological investigation of an outbreak of Weil's disease in northern Queensland, Med. J. Austr., 2, 597-605, 1934.

43) Lumley, G.F.: Leptospirosis in Queensland. A serological investigation leading to the discovery of distinct serological groups of leptospirae causing leptospirosis as it occurs in northern Queensland, with some other related observations; Med. J. Austr., 1, 654-664, 1937.

44) Shiosawa, S., Kitaoka, M. \& Inoue, K.: Studies on L. biflexa (III); Nihon Densenbyo-Gakkai Zasshi, 7, 1177-1196, 1933 (in Japanese).

45) Kitaoka, M. \& Inoue, K.: Epidemiological survey on Weil-leptospirosis (II) ; Nihon Densenbyo-Gakkai Zasshi, 8, 864-866, 1934 (in Japanese).

46) Taylor, J. \& Goyle, A. N.: Leptospirosis in Andamans, with appendix on present knowledge of leptospiral infections; Ind. Med. Research (memoir No. 20), 1-190, 1931.

47) Gispen, R. \& Schüffner, W.: Die Spaltung der klassischen Leptospira icterohaemorrhagiae s. icterogenes in zwei Biotypen; Zbl. Bakt., I, Orig., 144, 427-434, 1939.

48) Yamamoto S.: Leptospirosis in dogs (II); Types of leptospira from dogs; Nihon Juigaku Zasshi, 5, 1-44, 1943 (in Japanese).

49) Kitaoka, M., Sakamaki, Y. \& Ogawa, M.: Types among leptospira strains isolated from house rats in Tokyo; The Scientific Meeting of the Government Institute for Infectious Diseases, on Jan. 18, 1945 (reported in Japanese).

50) Ido, T., Ito, K. \& Wani, H.: Animal experiment on "Nanukayami" fever. Relation of "Nanukayami" fever in Fukuoka to "Sakushu" fever in Okayama, "Akiyami" in Shizuoka and an unknown febrile disease in Kyoto ; Nihon Naika-Gakkai Zasshi, 5, 130, 1917 (in Japanese). 
51) Koshina, M., Shiosawa, S. \& Kitayama, K.: Studies of L. hebdomadis; J. Exper. Med., 42, 873-885, 1925.

52) Abe, T., Tokunaga, T., Kaneko, M. Kotori, S. \& Aoki, Y.: On etiologic agent of an endemic febrile disease occurring in Hasami, Nagasaki; Nihon Densenbyo-Gakkai Zasshi, 7, 457-481, 1933 (in Japanese).

53) Sato, M.: On etiologic agent of so-called "Akke" disease (a febrile disease in Oita); Nihon Densenbyo-Gakkai Zasshi, 9, 237-263, 1934 (in Japanese).

54) Aoki, G.: Geographical distribution of leptospirosis in southern Kyushu; The 15th Rengo Biseibutsu Gakkai Kiroku, 390-391, 1941 (in Japanese).

55) Shimomura, T.: Studies on leptospirosis in Kochi (II) Serological investigation; Nihon Densenbyo-Gakkai Zasshi, 13, 1188-1210, 1936 (in Japanese).

56) Tagawa, S.: Studies on "Sakushu" fever (I); Okayama Igakkai Zasshi, No. 427, 832-843, 1925 (in Japanese).

57) Murakami, S., Miki, G. \& Miyakawa, F.: On the causative agent of "Sakushu" fever; Tokyo Iji-Shinshi, 6O, 3021-3027, 1936 (in Japanese).

58) Murakami, S., Miki, G., \& Abe, K.: On a febrile and icteric disease occurring in Okayama in the summer, 1935; Okayama Igakkai Zasshi 49, 635-642, 1937 (in Japanese).

59) Kitaoka, M., Ogawa, M., Murakami, S. \& Utsunomiya, S.: Serologica investigation with sera collected from "Akiyami" cases in Shizuoka, "Sakushu" cases in Okayama and "Odan-eki" cases in Kochi. Leptospira isolation from "Akiyami" cases; The Scientific Meeting of the Government Institute for Infectious Diseases, on May 20, 1943 (reported in Japanese).

60) Shiosawa, S. \& Kubo, I.: Studies on "Akiyami" leptospirosis; Nihon Densenbyo-Gakkai Zasshi, 17, 542-543, 1943 (in Japanese).

61) Kitaoka, M., Sakamaki, Y. \& Ogawa, M.: On manifest and subclinical infection of "Akiyami" fever in the area along the Tenryu River, in Shizuoka; The Scientific Meeting of the Government Institute for Infectious Diseases, on June 28, 1945 (reported in Japanese).

62) Kitaoka, M.: Epidemiological survey on "Akiyami" in the area along the Tenryu River in Shizuoka: Jikken-Igaku Zasshi, 28, 283-284, 1944 (in Japanese).

63) Kitaoka, M. \& Shoji, Y.: On the etiologic agent of so-called "Sawara" fever in Sawara Town, Chiba; The Scientific Meeting of the Government Institute for Infectious Disease, on March 22, 1945 (reported in Japanese).

64) Kitaoka, M., Sakamaki, Y. \& Shoji, Y.: Further studies on leptospirosis in villages in Ibaragi. Effect of vaccine; The Scientific Meeting of the Government Institute for infectious Diseases, on June 28, 1945 (reported in Japanese).

65) Kitaoka, M. \& Ogawa, M.: Manifest and subclinical infection of leptospirosis in villages in Gunma Prefecture; Jikken-Igaku Zasshi, 28, 63, 1944 (in Japanese).

66) Kitaoka, M., Ogawa, M. \& Sakamaki, Y.: Geographical distribution of leptospirosis in villages in Miyagi; The scientific Meeting of the Government Institute for Infectious Diseases, on June 28, 1945 (reported in Japanese). 
67) Vaucel, M.: Leptospirosis en Indochine Francaise, Types serologiques observes; Acta Con. Tert. Trop. Morb., Amst,, 372-380, 1938.

68) Fletcher, W.: Recent work on leptospirosis, tsutsugamushi disease, and tropical typhus in Federated Malay States; Tr. Roy. Soc. Trop. Med., 21, 265-288, 1927.

96) Mochtar, A., De Peede, C. A. en Rijkebusch, M.: Het voorkomen van nanukayami op Java; G. T. v. N. I., 81, 2492-2504, 1941.

70) Mino, P.: Sulla eziologia della leptospirosi nel Vercellese; Policlinico Sez. Prat., 46, 189-191, 1939.

71) Kitamura, K. \& Hara, S.: On etiologic agent of “Akiyami" fever; Tokyo Iji-Shinshi, No. 2056, 25-32; No. 2057, 116-122, 1918 (in Japanese).

72) Stefanopoulo, G. J. et Hosoya, S.: Sur les spirochétides agents de la "fievre d'automne" du Japon (Spirochaeta autumnalis, types A et B); C. r. Soc. Biol., 98, 1317-1320, 1928.

73) Hosoya, S. et Stefanopoulo, G. J.: Sur la différenciation du L. icteroides, du Spirochaeta icterohaemorrhagiae et du certains autres spirochétides visins; C. r. Soc. Biol., 97, 1447-1450, 1927.

74) Miyanaga, K.: Comparative studies of L. icterohaemorrhagiae and Lhebdomadis A; Aichi Igakkai Zasshi, 34, 1706, 1927 (in Japanese).

75) Kaneko, M.: Experimental studies on pathogenicity of L. icterohaemo* rrhagiae, especially by animal passage; Eiseigaku-Densenbyogaku Zasshi, 30, 187-188, 1934 (in Japanese).

76) Kitaoka, M.: Immunological relation of L. grippotyphosa to L. hebdomadis A; Jikken-Igaku Zasshi, 25, 362-363, 1941 (in Japanese).

77) Abe, T., Tokunaga, T., Kaneko, M., Kotori, S. \& Aoki, Y.: On the rat, natural reservoir of the causative agent of "Akiyami" in Hasami village in Nagasaki; Nihon Densenbyo-Gakkai Zasshi, 7, 565-578, 1933 (in Japanese).

78-a) Kitaoka, M. \& Ogawa, M.: Positive rate of leptospira among the rats caught in the infected area with Yosui disease along the Tenryu River; Nihon-Igaku, 2498-2503, 1942 (in Japanese).

78-b) Kitaoka, M., Ogawa, M. \& Murakami, S.: On leptospira isolated from the field-rats caught at the "Akiyami" fever endemic area in Shizuoka and the "Sakushu" fever endemic area in Okayama; Nihon DensenbyoGakkai Zasshi, 17, 543-544, 1943 (in Japanese).

79) Shiosawa, S.: Studies on "Akiyami" leptospirosis; Jikken-Iho, 25, 542543, 1939 (in Japanese).

80) Inoue, K. \& Kubo, I.: On leptospira isolated from the field rats in the "Akiyami" endemic area along the Tenryu River; Nihon DensenbyoGakkai Zasshi, 101, 1135-1137, 1936 (in Japanese).

81) Kitamura, K. \& Ide, S.: On an endemic disease like Weil's disease in the area along the Tenryu River in Shizuoka and its etiologic leptospira; Nihon Naika-Gakkai Zasshi, 16, 335-347, 1928 (in Japanese).

82) Shiosawa, S., Kitaoka, M. \& Masaki, K.: Identification of the leptospira isolated from the case of an endemic disease like Weil's disease in the area along the Tenryu River in Shizuoka; Tokyo Iji-Shinshi, 53, 24112416, 1929 (in Japanese).

83) Shiosawa, S. \& Kubo, I.: Isolation of a new species of leptospira from a case of "Akiyami" fever (so-called "Yosui" disease) in the area 
along the Tenryu River in Shizuoka (1) ; Tokyo Iji-Shinshi, 62 2I992203, 1938 (in Japanese).

84) Kitaoka, M., Sakamaki, Y. \& Ogawa, M.: Leptospira bataviae in Japan; The Scientific Meeting of the Government Institute for Infectious Diseases, on Nov. 16, 1944 (reported in Japanese)

85) Walch, E. W.: Demonstratle van een Leptospira, bij geisoleerd een patient, die klinisch het beeld van Weilsche ziekte had vertoond; G. T.v. N. I., 66, 115, 1926.

86) Mochtar, A. en Collier, W. A.: De L. javanica als een zelfstandige leptospira soort; G. T. v. N. I., 80, 131-137, 1940.

87) Mochtar, A., Djohan, B. en Wahab; Verdere utikomsten van het onderi zook van leptospirosis gevallen te Batavia; G. T. v. N. I., 81, 11-22, 1941.

88) Esseveld, H. en Collier, W. A.: Leptospirosis in cats in Batavia; Ovexgenomen Vit de Mededeelingen van den Dienst der Valksgenzondheid in Ned. Indie, 27, 250-261, 1938.

89) Esseveld, H. \& Collier, W.: Leptospirose bei Katzen auf Java; Z. Imm. Forschg., 93, 512-528, 1938.

90) Babudieri, B.: Leptospira oryzeti agente diuna muova leptospiprs italiana; Riv di parassitol., 3, 93-111, 1939.

91) Mino, P.: Eine neue Leptospirose bei den Reisarbeiten Oberitaliens; Acta Con. Tert. Trop. Morb., Amst., 422-424, 1938.

92) Mino, P.: Ueber Leptospirosen bei den Arbeitern der Reisfelder Oberita. liens ; Z. Immun. Forschg., 96, 466-485, 1939.

93) Schüffner, W. \& Klarenbeek, A.: Appearance in Holland of leptospira strain differing from Weil strain; Ned. Tijdschr. v. Geneesk, 77, 42714276, 1933.

94) Walch-Sorgdrager, B. \& Schüffner, W.: Die Selbstaendigkeit der L canicola ; Zbl. Bakt., Org., 141, 97-109, 1938.

95) van der Walle, N.: Leptospirose des chiens a anvers; Acta Con. Tert. Trop. Morb., Amst., 420-421, 1938.

96) Meyer, K. F., Eddie, B. \& Anderson-Stewart, B.: Canine, murine, and human leptospirosis in California; Proc. Soc. Exper. Biol. \& Med., 38, 17-19, 1938.

97) Elander, B. J. \& Perry, J. K.: Leptospirosis in dogs; J. Am. Vet. Med. Assn., 96, 511-514, 1940.

98) Schüffner, W.: Zu dem Artikel "Ueber Leptospirosen in Deutschland" von W. Rimpau, H. Schlossberger und J. Kathe; Zbl. Bakt., Org., 142, 220, 1938.

99) Schlossberger, H.: Bemerkungen zu den vorstehenden Ausführungen von Prof. Dr. Schüffner; Zbl. Bakt., 1, Orig., 142, 223-224, 1938.

100) Schlossberger, H. \& Pohlmenn, R.: Untersuchungen über Stuttgarter Hundescuche; Zbl. Bakt., 1, Orig., 136, 182, 1936.

101) Rimpau, W., Schlossberger, H. \& Kathe, J.: Ueber Leptospirosen in Deutschland ; Zbl. Bakt., I., Orig., 141, 318, 1938.

102) Kaufmann, O.: Vergleichende serologische Untersuchungen mit verschiedenen Staemmen der Spirochaeta icterogenes und mit der Spirochaeta canicola; Z. Imm. Forschg., 93, 354-367, 1938. 
103) Bessemans, A., Witlebolle, P. en de Borchgrave, O.: Serologische gegevens over Weil- en Hondenleptospiren; Acta Con Tert. Trop. Morb., Amst., 416-419, 1938.

104) Ohashi, M. \& Yoshida, Y.: Clinical and experimental studies on a Weil's disease-like disease in Okinawa (I); Tokyo Iji-Shinshi, 67, 3129-3131, 1938 (in Japanese).

105) Yamamoto, S. \& Hashikuchi, W.: Leptospira pyrogenes (Vervoort, 1923) in Okinawa ; Nihon Igaku, 379-382, 1944 (in Japanese).

106) Baermann, G. \& Snuts, E.: Diagnose, Klinik, Epidemiologie und Therapie der Kurzfristigen Weilschen Erkrankungen (III) ; Zbl. Bakt., I, Orig., 105, 368-383, 1928.

107) Vervoort, H.: Spirochaeten bij acute koorstige ziekten van onbekenden oorsprong in de tropen, Spirochaetosis febrilis; G. T. v. N. I., 63, 806, 1923.

108-a) Walch-Sorgdrager, B., Bohlander, L. en Schüffner, W. A. P.: Over leptospirosis in Australie en eenige operkingen over de soortbepaling der daar geisoleerde stammen; G. T. v. N. I., 78, 2299-2308, 1938.

108-b) Schüffner, W. \& Mochtar, A.: Gelbfieber und Weilsche Krankgeit; Arch. Sehiffs und Trop Hyg., 31, 149-165, 1927.

109) Kitaoka, M., Ogawa, M. \& Imai, M.: Weil's disease as occupational disease. Manifest and sub-clinical infection of Weil's disease among food sellers; Jikken-Igaku Zasshi, 17, 399-400, 1943 (in Japanese).

110) Kitaoka, M., Ogawa, M. \& Sakamaki, Y.: Manifest and sub-clinical infection of Weil's disease among food sellers in Tokyo; Nihon Naika-gakkai Zasshi, 78, 1944 (in Japanese).

111) Toyama, Y.: Preventive measures against Weil's disease from agricultural standpoint; Igaku-Chuo Zasshi, 20, 1123-1134, 1923 (in Japanese).

112) Kitaoka, M., Maida, D. \& Inoue, S.: A febrile disease in Kumamoto following the typhoon in July 1944; Igaku-Tsushin, No. 221, 4-6, 1950 (in Japanese).

113) Tarassoff, S.: Sur la découverte de l'agent infectieux de la Schlammfieber ou Léptospirosis grippo-typhosa aquatilis; Ann. Inst. Pasteur, 46, 222-225, 1931.

114) Tarassoff, S.: Note additionnelle sur l'agent infectieux de la Schlammfieber ou léptospirosis grippo-typhosa aquatilis; Ann. Inst. Pasteur, 46, 635-638, 1931.

115) Epstein, H. \& Tarassow, S.: Zur Aetiologie des sogenannte Schlamm-oder Wasser-fiebers; Arch. Schifrs u. Trop. Hyg., 33, 222-223, 1929.

116) Rimpau, W.: Ueber das Vorkommen von Schlamm-(Ernte-) Fieber in Südbayern im Sommer 1926; Münch. Med. Wschr., 74, 921-924, 1927.

117) Brill: Zur Aetiologie des Schlammfiebers. (Med. Universitaets-Poliklinik Hamburg-Eppendorf) ; Münch. Med. Wschr., 74, 1537-1540, 1927.

118) Dinger, J. E. et Werschaffelt, F.: Recherches expérimentales sur quelques souches de leptospires; Ann. Inst. Pasteur, 14, 396-414, 1930.

119) Hoffman, R.: Klinische Beobachtungen an Feldfiebererkrankungen des Jahres 1939; Deut. Med. Wschr., 66, 456-459, 1940.

120) Schulz, W.: Das Schlamm-oder Feld-fieber, eine Mitteilung über die Epidemie im Jahre 1939 im Kreise Ratibor; Deut. Med. Wschr., 66, 372$375,1940$. 
121) Yamamoto, S.: Classification of leptospira by means of agglutination test; The Scientific Meeting of the Government Inst. for Infect. Dis., on May 18, 1944 (reported in Japanese).

122) Rimpau, W.: Weiteres zur Epidemiologie des Feldfiebers in Südbayern; Münch. Med. Wschr., 85, 1977-1979, 1938.

123) Osterwald, K. H.: Zeitrag zum Vorkommen des sog. Feldfiebers; Med. Klin., 36, 1241-1242, 1940.

124) Baermann, G.: Die kurzfristigen Spirochaetenfieber; Handbuch d. Path. Mikro., 7, 661-690, 1930.

125) Baermann, G.: Klinische und experimentelle Untersuchungen über Spirochaetenerkrankungen und Spirochaeten (in Deli, S. O. K.); G. T. v. N. I., 63, 885, 1923.

126) Johnson, D. J. \& Brown, H. E.: Mild leptospirosis in southern Queensland; A classification of the infeeting leptospira and a report of eight further cases of the disease; Med. J. Austr., 1, 805-813, 1938.

127) Wolff, J. W.: Untersuchungen über Kultur und Serologie der Leptospiren; Areh. F. Schifîs, u. Trop. Hyg., 29, 111-128, 1925.

128) Mochtar, A. en Djohan, B.: Een geval van ziekie van Weil, veroorzookt door leptospira van het "Rachmat" type; G. T. v. I., N. 80, 2573-2578, 1940.

129) Mochtar, A.: Over het voorkomen. van Jeptospiras bij varkens te Batavia; G. T. v. N. I., $80,2334-2345,1940$.

130) Brown H. C.: Epidemic jaundice in the Andaman Islands; Lancet, 1, 388, 1.928.

131) Clayton, G. E. B., Derrick, E. H. \& Cilento, R.: The presenee of leptospirosis of a mild type (Seven-day fever) in Queensland; Med. J. Austr., 1, 647-654, 1937.

132) das Gupta, B. M.: Further observations on leptospiral infections in Calcutta ; J. Trop. Med. \& Hyg., 42, 123, 1939.

133) Bessemans, A. et Thisy, U.: Présence dans l'cau du distribution de la ville de Gand, d'un léptospire pseudo-ictérogène pathogène pour la souris; C. r. Soc. Biol., 99, 1881, 1928.

134) Sardjito, M.: Leptospirosis in Midden-Java met de seroreactie op verschillende typen van leptospirae; G. T. v. N. I., 80, 280-291, 1940.

135) Esseveld, H. en Mochtar, A.: Over het voorkomen van een niew leptospira-type (L. javaniea) en het Salinem-type bij veldratter op Java; G. T. v. N. I., 77, 1513-1522, 1938.

136) Mochtar, A. en Esseveld, H.: Over de frequentie van leptospirosis in Ned-Indie; G. T. v. N. I., 79, 547-563, 1939.

137) Sardjito, M. en Mochtar, A.: Een tweede leptospirastem uit veldrat Semarang 173 met een nieuw serologisch type en zijn verdere eigenschappen; G. T. v. N. I., 78, 2299-2308, 1938.

138) Collier, W. A. en Mochtar, A.: Een serologisch afwijkende leptospirastam uit de nier eener vleermuis; G. T. v. N. I., 79, 226-231, 1939.

139) Vaucel, M. et Soulier, R.: Sur l'existence d'un foyer de leptospirose à Tuyen-Quang (Tonkin); Bull. Soc. Path. Exot., 30, 408-416, 1937.

140) Esseveld, H.: Bijdrage tot het leptospirosis vraagstuk te Batavia naar aanleiding van seroreacties met leptospira-stammen bij "Widal" sera; G. T. v. N. I., 78, 2834-2844, 1938. 
141) Ido, T. \& Wani, H.: Relationship between the abortive form of Weil's disease and Nanukayami disease; Nihon Byorigakkai-Kaishi, 6, 193-197, 1916 (in Japanese).

142) Hamilton F. N.: Leptospirosis in the British Empire; Acta Tert Trop. Morb., Amst., 387-395, 1938.

143) Blumenberg, W.: Ueber den neuesten Stand der Epidemiologie der Weilschen Krankheit; Erg. Hyg., 22, 168-237, 1939.

144) Shiosawa, S. \& Kubo, I.: Leptospirosis icterohaemorrhagica and its related diseases ; Rinsho-Igaku, 31, 1330-134:3, 1943 (in Japanese).

145) Inada, R.: On leptospirosis; Nihon Densenbyo-Gakkai Zasshi, 9, 234-136, 1934 (in Japanese)

146) Shiosawa, S.: Autumn leptospirosis; Shindan to Chiryo, 22, 1329-2346, 1480-1492, 1935 (in Japanese).

147) Shiosawa, S.: Autumn leptospirosis and its causative agent; Jikken-Iho, 24, 1610-1618; 1771-1783, 1938 (in Japanese).

148) Shiosawa, S. \& Kubo, I.: Autumn leptospirosis ; Rinsho-Igaku, 29, 12131217, 1940 (in Japanese)

149) Shiosawa, S. \& Kubo, I.: Autumn leptospirosis ; Nihon Iji-Shimpo, 10631065, 1941 (in Japanese).

150) Niinome, K.: Studies on leptospira and its group; Jikken-Igaku Zasshi, 23, 107-133, 1939 (in Japanese).

151) Anjo, S.: Comparative Studies of resistence of leptospirae influenced from the outside; Iji-Shimbun, No. 1210, 473-499, 1927 (in Japanese).

152) Kimura, R. \& Higashi, N.: Classification of bacillus by means of electron microscope; Nihon Igaku, 236-244, 1944 (in Japanese).

153) Carlinfanti, E.: Studien über 'die Antigenen Eigenschaften der Spirochaeta icterohaemorrhagiae; Z. Imm. Forschg., 94, 426-436, 1938.

154) Okamoto, H.: Studies on variation of bacillus: Nihon Igaku, 32, 894907, 1943 (in Japanese).

155) Uhlenhuth, P.\& Herrmann, E.: Neue Untersuchungen über die Umwandludg der Spirochaeta pseudo-icterogenes (Wasserspirochacte) in die Spirochaeta icterogenes (Erreger der Weilschen Krankheit) ; Med. Kiln., 23, 599-601, 1927.

156) Baermann, G. \& Zuelzer, M.: Die Einheitlichkeit aller tier-und menschenpathogenen Spirochaeten von Typus der Spriochaeta icterogenes syn. icterohaemorrhagiae und der mit ihr verwandten Wasserspirochaete vom gleichen Typus; Zbl. Bakt., 1, Orig., 105, 345-367, 1928.

157) Sardjito, M.: Umwandlung von Antigenen Eigenschaften und zugleich avirulent werden eines Rettenleptospirastammes durch Zuechtung von Wasser; Zbl. Bakt., 1, Orig., 126, 395-403, 1932.

158) Kitaoka, M.: Studies on L. biflexa (IV), Animal passage; Nihon Densenbyo-Gakkai Zasshi, 7, 46-68, 1942 (in Japanese).

159) Tsuge, K.: Agglutinability of L. hebdomadis; Aichi Igakkai Zasshi, 30, 278-285, 1923 (in Japanese).

160) Sugimoto, H.: Studies on L. biflexa (IV), Its pathogenicity; Juzenkai Zasshi, 4O, 2655-2669, 1935 (in Japanese).

161) Matsuzaki, H.: Monitic theory of both Weil's and Nanukayami diseases: Chiryo oyobi Shoho, 1, No. 10, $1920^{\circ}$ (in Japanese). 
162) Zuelzer, M.: Zur Biologie und Epidemiologie der Weilschen Krankheit, Mit besonderer Brücksichtigung von Daenemark; Zbl. Bakt., 1, Orig., 127, 189-205, 1936.

163) Ohashi, M. \& Hashiguchi, W.: On the leptospira isolated from the rats and the patients like Weil's disease; Tokyo Iji-Shinshi, 63, 889-893, 1939 (in Japanese).

164) Rosenbaum, H. D.: Canicola fever; case report and review of literature; Arch. Int. Med., 78, 531-543, 1946.

165) Meyer, K. F., Molner, J. G. \& Raskin, H. A.: Leptospiral infection; survey; J. A. M. A., 136, 814-819, 1948.

166) Stavitsky, A. B.: Spirochetosis with special reference to the mechanisms of host resistence; Bact. Rov., 12, 203-255, 1948.

167) Alston, J. M. et al.: Diseussion on leptospirosis; Proc. Roy. Soc. Med., 42, 707-720, 1949.

168) Borg-Peterson, C.: Leptospira ballum; a new serological leptospira type ? Acta Path. ct Microbiol. Scand., 21, 504. 5044.

169) Btesh, S.: Infection of man with L. bovis in Palestina: Tr. Roy. Soc. Trop. Med. \& Hyg., 41, 419-426, 1947-48.

170) Wolff, J. W.: Observation on the serological typing of leptospira strains. A plea for unification and standardization of laboratory methods; The fifth Intern. Microbiol. Congr., Brazil, 78-79, 1950.

171) Bernkopf, H., Olitzki, L. \& Stuezynski, L. A.: Studies on bovine and human leptospirosis; J. Infect. Dis., 80, 53-63, 1947.

172) Ungar, H. \& Bernkopf, H.: Bovine leptospirosis; Pathologic observation on experimentally infected calves; Arch. Path., 44, 59-70, 1947.

173) Baker, J. A. \& Little, R. B.: Leptospirosis in cattle; J. Exper. Med., 88, . 295-308, 1948.

174) Guida, V.: Occurence of leptospirae in domestic animls in Sao Paulo, Brazil; The Fifth Intern. Congr. Microbiol., Brazil, 95, 1950.

175) Guida, V.: Serological research on a leptospira strain isolated from pigs; The Fifth Intern. Congr. Microbiol., Brazil, 95, 1950. 


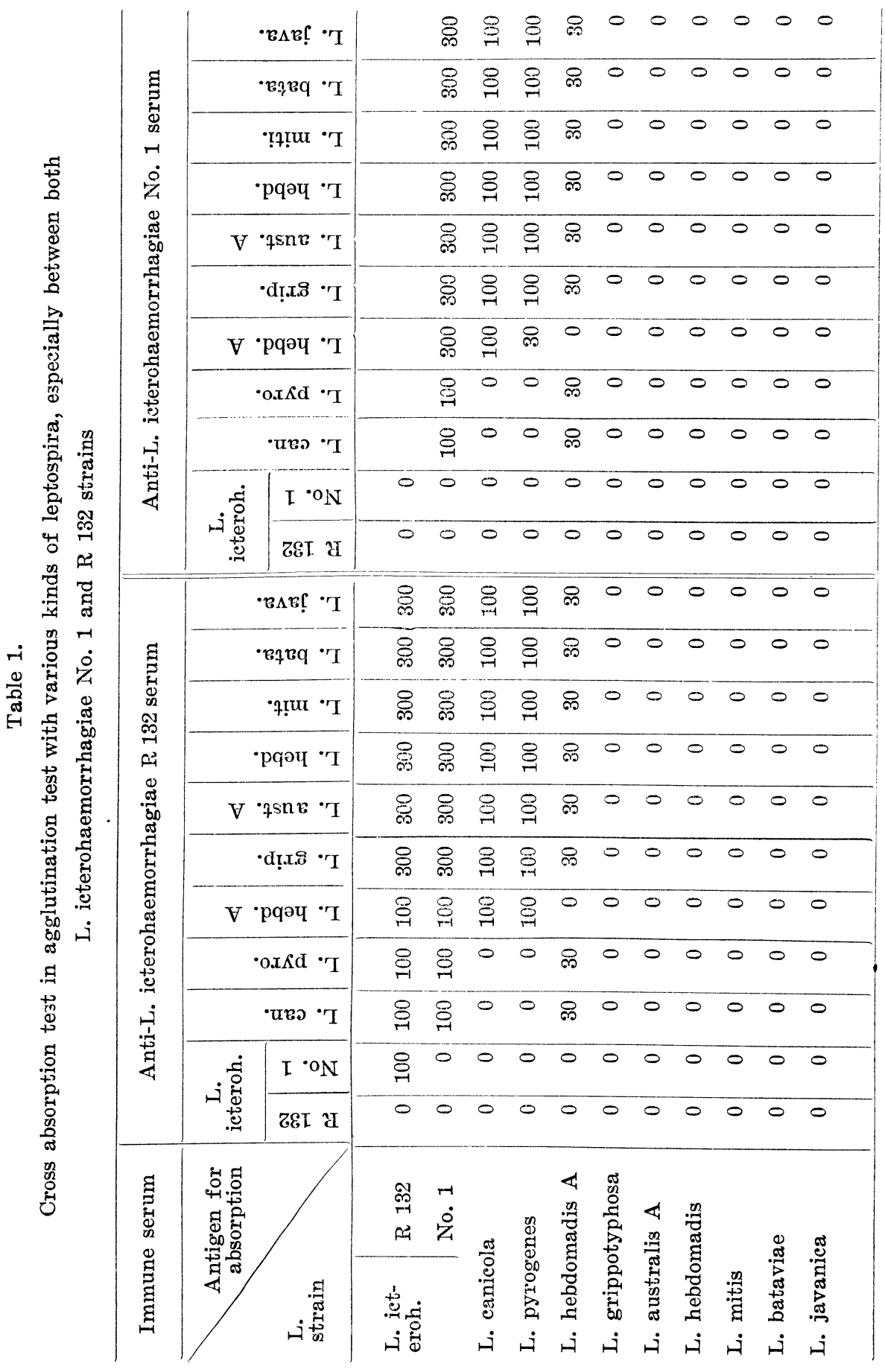


LEPTOSPIRA

\begin{tabular}{|c|c|c|c|c|c|c|c|c|c|c|c|c|}
\hline & & 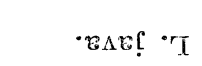 & 0 & 0 & 0 & 0 & 0 & 0 & 0 & 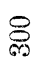 & 命 & 0 \\
\hline & & 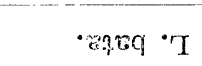 & 0 & 0 & 0 & 0 & 0 & 0 & 0 & 0 & 0 & 0 \\
\hline & & I & 0 & 0 & 0 & 0 & 0 & 0 & 0 & 0 & 0 & 0 \\
\hline 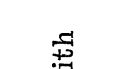 & $\stackrel{g}{:}$ & $\cdot$ pqәч $\cdot T$ & 0 & 0 & 0 & 0 & 0 & 0 & 0 & 8 & 8 & 0 \\
\hline$\triangleq$ & 量 & $\mathrm{H}^{\cdot} \mathrm{7sn} 6 \cdot \mathrm{T}$ & 0 & 0 & 0 & 0 & 0 & 0 & 0 & 8 & 8 & 0 \\
\hline & نَّـ & $\cdot d ! x . P^{\prime} I$ & 0 & 0 & 0 & 0 & 0 & 0 & 0 & $\stackrel{8}{60}$ & $\underset{8}{8}$ & 0 \\
\hline ฮే & 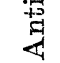 & 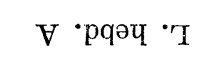 & 0 & 0 & 0 & 0 & 0 & 0 & 0 & $\stackrel{8}{\%}$ & ڤ్ & 0 \\
\hline 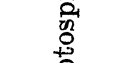 & & $\cdot 0 x \Lambda d \cdot T$ & 0 & 0 & 0 & 0 & 0 & 0 & 0 & 8 & 8 & 0 \\
\hline$\stackrel{0}{0}$ & & •!̣uвว • $\mathrm{T}$ & 0 & 0 & 0 & 0 & 0 & 0 & 0 & ฉి & 8 & 0 \\
\hline 苞 & & əqə! • $\mathrm{I}$ & 0 & 0 & 0 & 0 & 0 & 0 & 0 & 尺्. & 8 & 0 \\
\hline 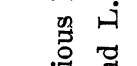 & & $\cdot 8 \Delta e\left[{ }^{-} \mathrm{I}\right.$ & 0 & 0 & 0 & 0 & 0 & 0 & 8 & 0 & 0 & 0 \\
\hline 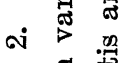 & & $\cdot 8 q \mathrm{~Bq} \cdot \mathrm{T}$ & 0 & 0 & 0 & 0 & 0 & 0 & $\underset{6}{8}$ & 0 & 0 & 0 \\
\hline 节 & & $\cdot$ & 0 & 0 & 0 & 0 & 0 & 0 & 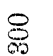 & 0 & 0 & 0 \\
\hline 章 & $\begin{array}{l}J_{0} \\
0 \\
02\end{array}$ & $\cdot$ pqәч •T & 0 & 0 & 0 & 0 & 0 & 0 & 0 & 0 & 0 & 0 \\
\hline 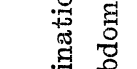 & 焉 & $\mathrm{V} \cdot$ ' & 0 & 0 & 0 & 0 & 0 & 0 & $\underset{\infty}{8}$ & 0 & 0 & 0 \\
\hline تُ & ت्ञ & • dị...8 • $\mathrm{I}$ & 0 & 0 & 0 & 0 & 0 & 0 & 禺 & 0 & 0 & 0 \\
\hline. & 章 & $\mathrm{V} \cdot$ 'рqәч ${ }^{\cdot T}$ & 0 & 0 & 0 & 0 & 0 & 0 & 8 & 0 & 0 & 0 \\
\hline 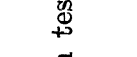 & & $\cdot 0 \pi \Lambda d{ }^{\bullet} \mathrm{I}$ & 0 & 0 & 0 & 0 & 0 & 0 & 8 & 0 & 0 & 0 \\
\hline 串 & & 'T ' & 0 & 0 & 0 & 0 & 0 & 0 & 8ి & 0 & 0 & 0 \\
\hline$\frac{n}{\sigma}$ & & ${ }^{\circ}$ oqว! $\bullet^{\cdot} \mathrm{T}$ & 0 & 0 & 0 & 0 & 0 & 0 & 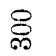 & 0 & 0 & 0 \\
\hline ơ & 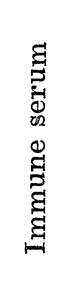 & $\begin{array}{l}\text {.0. } \\
\text {. } \\
\text {. } \\
\text {. } \\
0.00 \\
.00\end{array}$ & 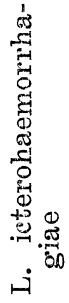 & 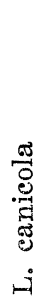 & 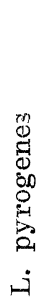 & 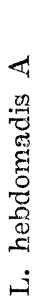 & 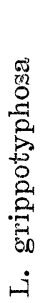 & 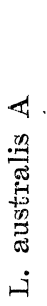 & 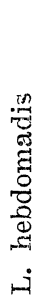 & 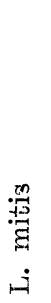 & 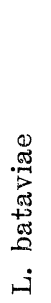 & 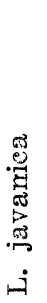 \\
\hline
\end{tabular}




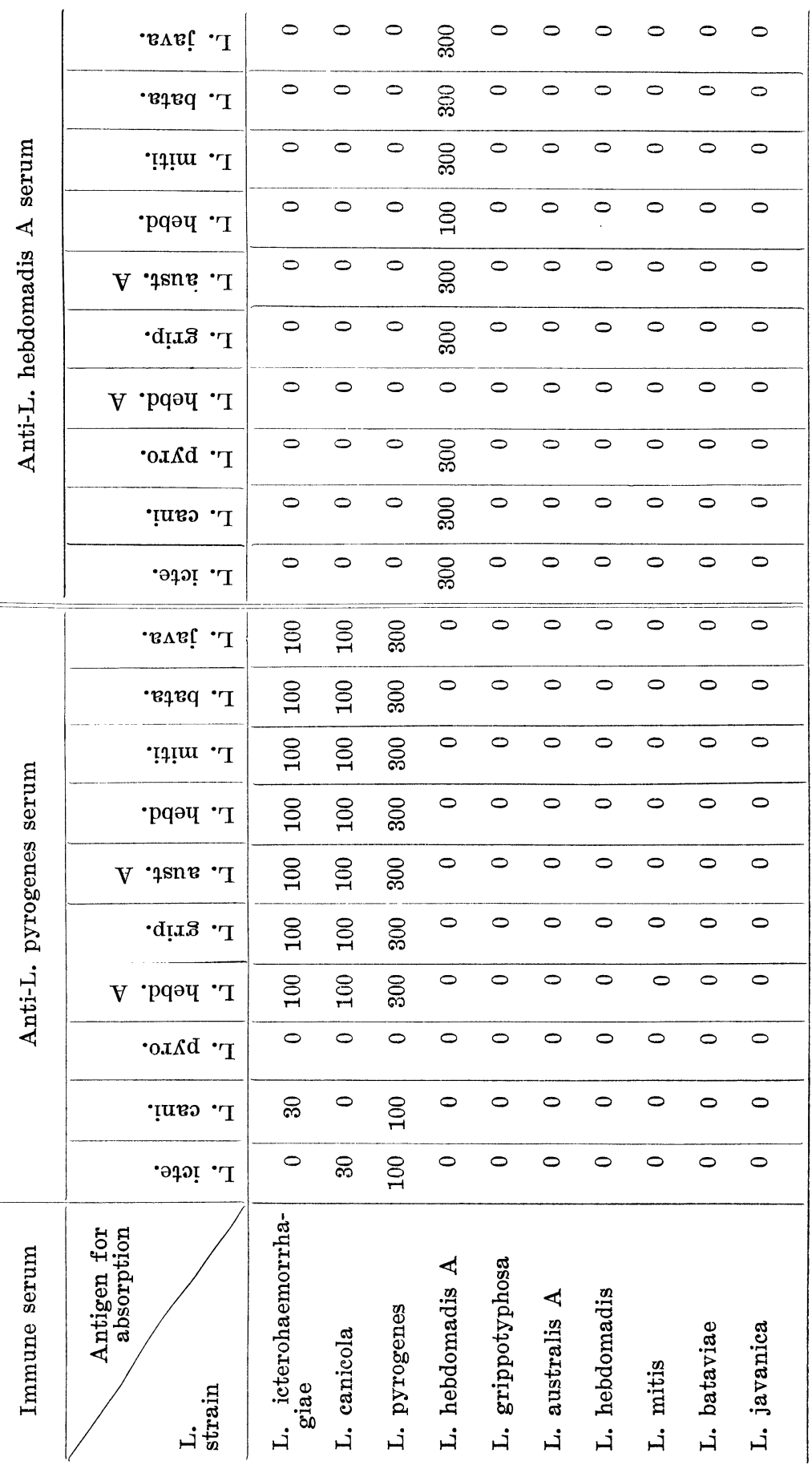




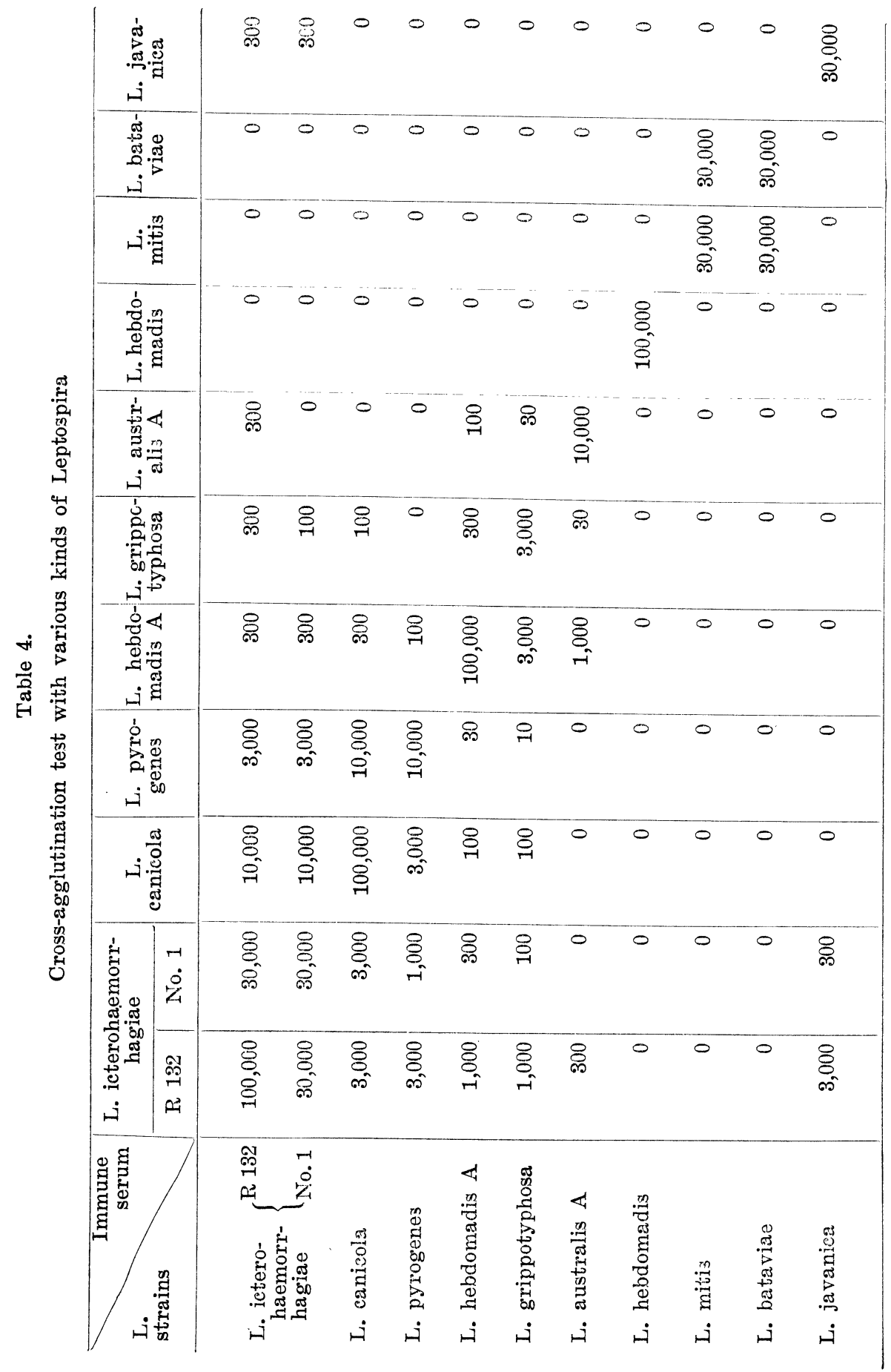




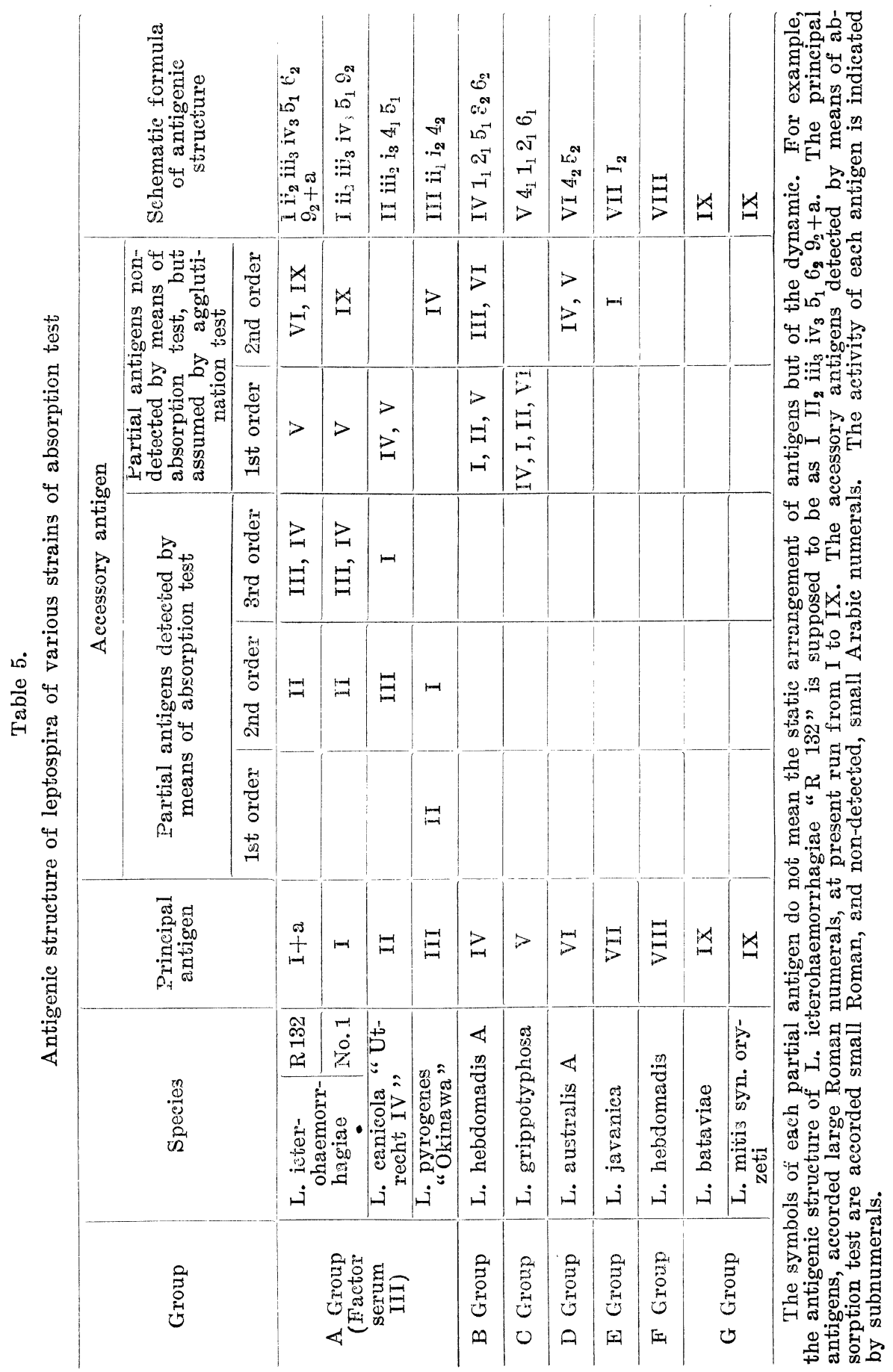

